\title{
Studi Literature: Analisis Pengaruh Pengetahuan Kewirausahaan Terhadap Minat Berwirausaha Siswa SMK
}

\author{
Teguh Wijaksana Isma ${ }^{1^{*}}, \mathrm{M}$ Giatman ${ }^{2}, \mathrm{E} \mathrm{Nazar}^{3}$ \\ 1, 2, ${ }^{3}$ Universitas Negeri Padang, Indonesia \\ *e-mail: teguhwijaksana@gmail.com
}

\begin{abstract}
One of the ways that the Indonesian government can overcome the problem of unemployment is to increase entrepreneurial interest early on. However, low interest in entrepreneurship is one of the problems that must be solved, especially in vocational school students where vocational school graduates are graduates who are ready to work. Various factors arise that make entrepreneurial interests low, including not confident, lazy, lack of money, and the latter is a lack of knowledge about entrepreneurship. Entrepreneurial knowledge is one of the important aspects in increasing entrepreneurial interest, because if you have good entrepreneurial knowledge can increase confidence in entrepreneurship. The purpose of this research was to analyze the influence of entrepreneurial knowledge on entrepreneurial interests in vocational school students. The type of research conducted is literature studies. Data is collected by browsing references on the internet. From the search that has been done obtained 21 references that correspond to what you want to research, namely about the influence of entrepreneurial knowledge on the entrepreneurial interests of vocational students. Based on the results of literature studies that have been conducted, from 21 references obtained 18 references concluded there was an influence of entrepreneurial knowledge or $85.71 \%$ while 3 references concluded there was no influence of entrepreneurial knowledge or $14.29 \%$. So it can be concluded that entrepreneurial knowledge affects the entrepreneurial interests of vocational school students.
\end{abstract}

Keywords: entrepreneurship; entrepreneurship knowledge, interest in entrepreneurship

\begin{abstract}
Abstrak: Salah satu cara yang dapat dilakukan oleh pemerintah Indonesia untuk mengatasi masalah pengangguran adalah dengan meningkatkan minat berwirausaha sejak dini. Namun rendahnya minat bewirausaha menjadi salah satu permasalahan yang harus diselesaikan, terutama pada siswa SMK dimana lulusan SMK merupakan lulusan yang siap untuk bekerja.Berbagai faktor muncul yang membuat minat berwirausaha rendah, diantaranya tidak percaya diri, malas, kurang modal, dan yang terakhir adalah kurangnya pengetahuan tentang wirausaha.Pengetahuan kewirausahaan merupakan salah satu aspek penting dalam meningkatkan minat berwirausaha, karena apabila memiliki pengetahuan kewirausahaan yang baik dapat meningkatkan kepercayaan diri dalam berwirausaha.Tujuan dari penelitian ini dilakukan adalah untuk menganalisis pengaruh dari pengetahuan kewirausahaan terhadap minat berwirausaha pada siswa SMK.Jenis penelitian yang dilakukan adalah studi literatur. Data dikumpulan dengan cara menelusuri referensi di internet. Dari penelusuran yang telah dilakukan didapatkan 21 referensi yang sesuai dengan yang ingin diteliti yaitu tentang pengaruh dari pengetahuan kewirausahaan terhadap minat berwirausaha siswa SMK. Berdasarkan hasil studi literature yang telah dilakukan, dari 21 referensi yang didapatkan 18 referensi menyimpulkan terdapat pengaruh pengetahuan kewirausahaan atau $85.71 \%$ sedangkan 3 referensi menyimpulkan tidak terdapat pengaruh pengetahuan kewirausahaan atau
\end{abstract}


14.29\%. Sehingga dapat disimpulkan bahwa pengetahuan kewirausahaan berpengaruh terhadap minat berwirausaha siswa SMK.

Kata Kunci: kewirausahaan; pengetahuan kewirausahaan, minat berwirausaha

Copyright (c) 2021 The Authors. This is an open access article under the CC BY-SA 4.0 license (https://creativecommons.org/licenses/by-sa/4.0/)

\section{PENDAHULUAN}

Data dari Badan Pusat Statistik (BPS) melaporkan bahwa angka pengangguran di Indonesia meningkat dari bulan Februari 2020 hingga Februari 2021. Data tersebut menjelaskan bahwa jumlah pengangguran di Indonesia bertambah sebanyak 1,82 juta sehingga total jumlah pengangguran di Indonesia menjadi 8,75 juta jiwa. Kepala BPS Suhariyanto menjelaskan bahwa peningkatan jumlah pengangguran di Indonesia diakibatkan oleh pandemic virus Covid-19 yang terjadi di Indonesia (Siregar, 2021).

Namun, hal tersebut dapat diatasi apabila generasi muda memiliki keberanian memulai bisnis baru atau menjadi pengusaha. Oleh karena itu, kewirausahaan merupakan salah satu cara yang lebih baik untuk membangun perekonomian di Indonesia. Pemerintah tidak akan mampu menggarap semua aspek pembangunan karena membutuhkan banyak anggaran, personel, dan pengawasan. Jadi, ditinjau dari segi kuantitas dan kualitas wirausaha itu sendiri, wirausaha merupakan potensi dalam pengembangan aspek perekonomian (Irda, 2019).

Namun, dalam bidang kewirausahaan permasalahan yang terjadi adalah rendahnya minat dalam berwirausaha, terutama siswa SMK. Padahal dengan bekal kompetensi kejuruan yang didapatkan, lulusan SMK lebih mampu untuk mengaplikasikan pengetahuan dan skill dalam dunia kerja atau sampai dengan tahap membuat lapangan kerja dengan menjadi seorang wirausahawan dibandingkan dengan lulusan lainnya (Srigustini, 2014). Alasan rendahnya minat siswa untuk berwirausaha antara lain: Bergengsi, tidak percaya diri, dan merasa tidak mampu menarik pembeli (malas). Adapun faktor eksternal yang disebabkan oleh kurangnya dana, Kesulitan dalam mengalokasikan waktu dan takut tidak melihat pengalaman orang laindan kurangnya pengetahuan tentang kewirausahaan (Mardatilah, 2020).

Salah satu cara untuk mengembangkan manusia dengan etika, sikap, dan keterampilan kewirausahaan adalah melalui pendidikan. Melalui pendidikan akan 
meningkatkan minat terhadap perilaku yang dipelajari. Kurikulum kewirausahaan sekolah membuat siswa lebih termotivasi untuk menjadi wirausaha (Soemanto, 2008). Semakin tinggi pengetahuan kewirausahaan siswa SMK maka semakin luas wawasan kewirausahaannya. Idealnya, sekolah dapat membantu siswa mengembangkan minat berwirausaha.Namun, masih banyak SMK yang hanya fokus pada pembelajaran IPA, dan belum ada lingkungan sekolah yang dapat mengatur minat wirausaha siswa.

Pengetahuan kewirausahaan merupakan salah satu insentif untuk merangsang minat berwirausaha. Mereka yang telah mendapatkan pelatihan, seminar dan kursus kewirausahaan akan tertarik pada kewirausahaan. Adanya pengetahuan memungkinkan manusia untuk mengembangkan keterampilan yang berguna bagi kehidupannya. Demikian juga dengan pengetahuan tentang kewirausahaan juga memiliki peran yang sangat penting dalam kegiatan bisnis karena pengetahuan kewirausahaan merupakan dasar dari sumber kekuatan bisnis yang terdapat pada individu (Ariesta, 2017).

Mata pelajaran kewirausahaan merupakan salah satu bentuk membekali mahasiswa dengan pengetahuan kewirausahaan dan membuat mereka tertarik untuk berwirausaha. Materi pembelajaran kewirausahaan, yang memuat hal-hal yang berhubungan dengan kewirausahaan seperti langkah dalam berwirausaha, proses dalam menjalankan usaha, dll.Seorang manusia dapat berkembang dengan ilmu pengetahuan. Salah satunya kewirausahaan, pengetahuan kewirausahan sangat penting dalam berwirausaha, karena pengetahuan adalah sumber dai menjalankan segala sesuatu (Irda, 2019).

\section{METODE}

Metode penelitian yang dilakukan adalah studi literature. Penelitian dilakukan dengan cara menelusuri jurnal di berbagai media elektronik, salah satunya adalah menggunakan Google Cendekia atau Google Scholar. Kata kunci yang digunakan adalah kewirausahaan, pengetahuan kewirausahaan, dan minat berwirausaha.Jurnal yang dipilih adalah dari tahun 2010 sampai sekarang.Jurnal yang dipilih adalah jurnal yang terindeks sinta nasional mulai dari sinta 5 sampai sinta 1. Dari jurnal yang diperoleh, dipilih yang memenuhi kriteria yaitu yang menyediakan data tentang pengaruh pengetahuan kewirausahaan terhadap minat 
berwirausaha. Dari penelusuran yang telah dilakukan didapatkan 21 jurnal yang berhubungan dengan pengaruh pengetahuan kewirausahaan terhadap minat berwirausaha pada tingkatan SMK. Analisa dengan melihat apakah ada pengaruh dari pengetahuan kewirausahaan terhadap minat berwirausaha siswa SMK.

\section{HASIL DAN PEMBAHASAN}

\section{Hasil}

Setelah dilakukan penelusuran pada Google Cendekia, diperoleh hasil sebanyak 21 jurnal dengan kata kunci pengetahuan kewirausahaan dan minat berwirausaha. Hasil analisis pengaruh pengetahuan kewirausahaan terhadap minat berwirausaha dapat dilihat pada tabel 1:

Tabel 1. Hasil Analisis Pengaruh Pengetahuan Kewirausahaan Terhadap Minat Berwirausaha

\begin{tabular}{|c|c|c|c|c|}
\hline NO & NAMA & TAHUN & TINGKATAN & SIMPULAN \\
\hline 1 & Lisa Indriyani & 2018 & SMK & $\begin{array}{l}\text { Ada pengaruh antara } \\
\text { pengetahuan kewirausahaan } \\
\text { dengan minat berwirausaha }\end{array}$ \\
\hline 2 & Sundari & 2018 & SMK & $\begin{array}{l}\text { Ada pengaruh antara } \\
\text { pengetahuan kewirausahaan } \\
\text { dengan minat berwirausaha }\end{array}$ \\
\hline 3 & $\begin{array}{l}\text { M. Fachry } \\
\text { Nasution }\end{array}$ & 2019 & SMK & $\begin{array}{l}\text { Ada pengaruh antara } \\
\text { pengetahuan kewirausahaan } \\
\text { dengan minat berwirausaha }\end{array}$ \\
\hline 4 & Dudung Abdullah & 2019 & SMK & $\begin{array}{l}\text { Ada pengaruh antara } \\
\text { pengetahuan kewirausahaan } \\
\text { dengan minat berwirausaha }\end{array}$ \\
\hline 5 & Siti Juhariyah & 2018 & SMK & $\begin{array}{l}\text { Ada pengaruh antara } \\
\text { pengetahuan kewirausahaan } \\
\text { dengan minat berwirausaha }\end{array}$ \\
\hline 6 & Siti Farida & 2016 & SMK & $\begin{array}{l}\text { Ada pengaruh antara } \\
\text { pengetahuan kewirausahaan } \\
\text { dengan minat berwirausaha }\end{array}$ \\
\hline 7 & Ermawati & 2015 & SMK & $\begin{array}{l}\text { Ada pengaruh antara } \\
\text { pengetahuan kewirausahaan } \\
\text { dengan minat berwirausaha }\end{array}$ \\
\hline 8 & $\begin{array}{l}\text { Muhammad Eko } \\
\text { Nur Syafii }\end{array}$ & 2015 & SMK & $\begin{array}{l}\text { Ada pengaruh antara } \\
\text { pengetahuan kewirausahaan } \\
\text { dengan minat berwirausaha }\end{array}$ \\
\hline 9 & Meri Rahmania & & SMK & $\begin{array}{l}\text { Ada pengaruh antara } \\
\text { pengetahuan kewirausahaan } \\
\text { dengan minat berwirausaha }\end{array}$ \\
\hline
\end{tabular}




\begin{tabular}{|c|c|c|c|c|}
\hline 10 & $\begin{array}{l}\text { Muhammad } \\
\text { Jailani }\end{array}$ & 2017 & SMK & $\begin{array}{l}\text { Ada pengaruh antara } \\
\text { pengetahuan kewirausahaan } \\
\text { dengan minat berwirausaha }\end{array}$ \\
\hline 11 & Dede Kurnia & 2018 & SMK & $\begin{array}{l}\text { Ada pengaruh antara } \\
\text { pengetahuan kewirausahaan } \\
\text { dengan minat berwirausaha }\end{array}$ \\
\hline 12 & $\begin{array}{l}\text { Untag Teddy } \\
\text { Wijaya }\end{array}$ & 2014 & SMK & $\begin{array}{l}\text { Ada pengaruh antara } \\
\text { pengetahuan kewirausahaan } \\
\text { dengan minat berwirausaha }\end{array}$ \\
\hline 13 & Dini Agusmiati & 2018 & SMK & $\begin{array}{l}\text { Tidak Ada pengaruh antara } \\
\text { pengetahuan kewirausahaan } \\
\text { dengan minat berwirausaha }\end{array}$ \\
\hline 14 & $\begin{array}{l}\text { Yulvitriyani Br } \\
\text { Sebayang }\end{array}$ & 2018 & SMK & $\begin{array}{l}\text { Ada pengaruh antara } \\
\text { pengetahuan kewirausahaan } \\
\text { dengan minat berwirausaha }\end{array}$ \\
\hline 15 & Bety Anggraeni & 2015 & SMK & $\begin{array}{l}\text { Ada pengaruh antara } \\
\text { pengetahuan kewirausahaan } \\
\text { dengan minat berwirausaha }\end{array}$ \\
\hline 16 & Eka Aprilianty & 2012 & SMK & $\begin{array}{l}\text { Ada pengaruh antara } \\
\text { pengetahuan kewirausahaan } \\
\text { dengan minat berwirausaha }\end{array}$ \\
\hline 17 & Novita Sari & 2018 & SMK & $\begin{array}{l}\text { Ada pengaruh antara } \\
\text { pengetahuan kewirausahaan } \\
\text { dengan minat berwirausaha }\end{array}$ \\
\hline 18 & Catur Setiarini & 2017 & SMK & $\begin{array}{l}\text { Ada pengaruh antara } \\
\text { pengetahuan kewirausahaan } \\
\text { dengan minat berwirausaha }\end{array}$ \\
\hline 19 & $\begin{array}{l}\text { Rifa'atul } \\
\text { Maftuhah }\end{array}$ & 2015 & SMK & $\begin{array}{l}\text { Ada pengaruh antara } \\
\text { pengetahuan kewirausahaan } \\
\text { dengan minat berwirausaha }\end{array}$ \\
\hline 20 & Novi Trisnawati & 2014 & SMK & $\begin{array}{l}\text { Tidak Ada pengaruh antara } \\
\text { pengetahuan kewirausahaan } \\
\text { dengan minat berwirausaha }\end{array}$ \\
\hline 21 & Asti Iswandari & 2013 & SMK & $\begin{array}{l}\text { Tidak Ada pengaruh antara } \\
\text { pengetahuan kewirausahaan } \\
\text { dengan minat berwirausaha }\end{array}$ \\
\hline
\end{tabular}

Berdasarkan tabel 1 dapat dilihat bahwa dari 21 jurnal yang didapatkan, 18 diantaranya menyimpulkan bahwa terdapat pengaruh yang positif antara pengetahuan kewirausahaan dengan minat berwirausaha. Sedangkan, 3 diantaranya menyimpulkan bahwa tidak terdapat pengaruh antara pengetahuan wirausaha dengan minat berwirausaha. Hasil persentase dari perbandingan antara ada atau 
tidak pengaruh pengetahuan kewiraushaan dengan minat berwirausaha siswa SMK dapat dilihat pada gambar 1 .

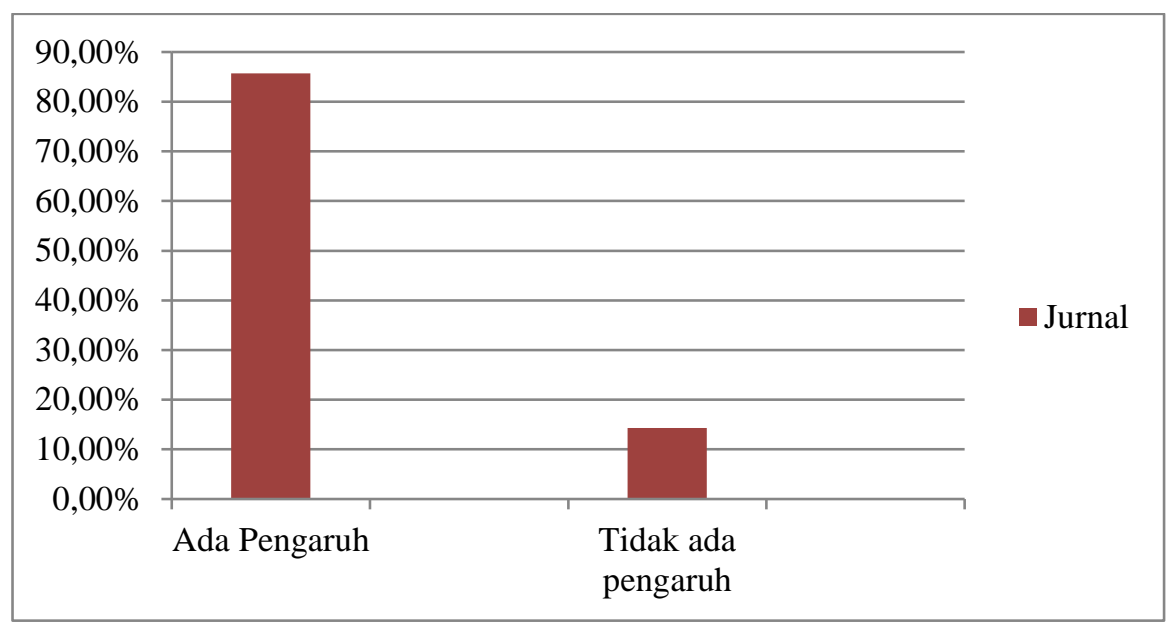

Gambar 1. Persentase Tabel 1

Dari 21 jurnal yang didapatkan, persentase terdapat pengaruh pengetahuan kewirausahaan terhadap minat berwirausaha adalah $85.71 \%$, sedangkan $14.29 \%$ tidak terdapat pengaruh pengetahuan kewirausahaan terhadap minat berwirausaha. Dengan persentase yang tinggi, dapat disimpulkan bahwa pengetahuan kewirausahaan merupakan salah satu syarat yang penting dalam mempengaruhi minat siswa untuk berwirausaha. Pengetahuan kewirausahaan yang dimiliki siswa terdiri dari beberapa indikator yaitu, pengetahuan bisnis yang akan dimasuki/diciptakan, pengetahuan peran dan tanggung jawab, pengetahuan manajemen bisnis dan organisasi.

\section{Pembahasan}

Hasil penelitian ini didukung oleh pendapat dari Nasution \& Panggabean (2019) yang menyatakan bahwa pengetahuan kewirausahaan secara parsial berpengaruh positif dan signifikan terhadap minat berwirausaha. Dalam penelitian yang lain juga menjelaskan bahwa apabila siswa memiliki pengetahuan yang baik tentang kewirausahaan, maka akan meminimalisir kegagalan yang disebabkan oleh faktor internal maupun eksternal (Anggraeni \& Bety, 2015). Selain dengan menanamkan pengetahuan teoritis kepada siswa SMK, pengetahuan yang diberikan dapat juga berupa pengetahuan praktek dengan kegiatan kegiatan-kegiatan kewirausahaan, sehingga siswa juga mempunyai keterampilan dalam berwirausaha (Wijaya, 2014). 
Selain itu hasil ini sesuai dengan Theory of Planned Behavior (TPB) keputusan dalam berwirausaha salah satu faktor yang mempengaruhi adalah pembelajaran. Hasil penelitian ini juga sesuai dengan pendapat (Suryana, 2013) bahwa Pengetahuan kewirausahaan dapat diperoleh melalui pembelajaran, antara lain pembelajaran di kelas dan pembelajaran ekstra kurikuler. Wirausahawan tanpa pengetahuan, kemampuan, dan tidak akan berhasil. Dengan kemauan, tetapi tanpa kemampuan dan pengetahuan, sulit untuk berkembang dan berhasil. Sebaliknya, orang yang memiliki pengetahuan dan kemampuan, tetapi tanpa kemauan, tidak akan menjadi seorang wirausahawan.

Pengetahuan merupakan kemampuan dasar yang harus dimiliki setiap orang. Dengan pengetahuan yang ada, seseorang dapat berkreasi dan berinovasi, karena dengan pengetahuan seseorang akan lebih mudah untuk berkreasi dan berinovasi karena memiliki bahan untuk mengembangkan keterampilan berpikir. Tanpa ditemani pengetahuan dan pengalaman yang tinggi, tidak mungkin menumbuhkan minat berwirausaha dan menjadi wirausahawan yang sukses. Jika siswa memahami dengan benar semua karakteristik dunia bisnis, siswa akan tertarik untuk berwirausaha. Pemahaman siswa tidak sepihak atau siswa hanya memahami sebagian dari kewirausahaan, tetapi siswa harus memahami sepenuhnya seluk beluk kewirausahaan. Jika siswa hanya memahami beberapa karakteristik kewirausahaan, mereka akan sering gagal karena mereka tidak dapat sepenuhnya menganalisis faktor internal dan eksternal yang dapat mendukung keberhasilan usaha.

Maka, pengetahuan kewirausahaan di sekolah diharapkan menjadi landasan teori konsep kewirausahaan dan membentuk mentalitas, sikap dan perilaku wirausahawan, yang dapat membekali wirausahawan terutama siswa dengan pengetahuan atau gambaran. Pengetahuan kewirausahaan adalah pemahaman seseorang tentang kewirausahaan, dengan berbagai kepribadian yang positif, kreatif, dan inovatif, serta mengembangkan peluang bisnis menjadi peluang bisnis yang bermanfaat bagi dirinya dan masyarakat konsumennya. Orang dengan pengetahuan kewirausahaan dapat mengetahui apa yang harus dilakukan untuk memulai bisnis. Dengan sekolah memberikan pengetahuan kewirausahaan yang baik ke siswa, bisa menjadi pedoman dan pemicu semangat siswa dalam berwirausaha kedepannya. 


\section{SIMPULAN}

Berdasarkan hasil penelitian yang telah dipaparkan, maka dapat disimpulkan bahwa dengan meningkatkan pengetahuan kewirausahaan siswa di sekolah dapat meningkatkan minat siswa untuk berwirausaha.hal ini dapat dilihat dari 21 referensi yang telah didapatkan 18 referensi mengatakan terdapat pengaruh pengetahuan kewirausahaan sedangkan yang lainnya tidak terdapat pengaruh pengetahuan kewirausahaan.

Idealnya, SMK selalu menanamkan pengetahuan kewirausahaan yang mendalam agar siswa lebih tertarik pada kegiatan kewirausahaan. Selain itu, dalam proses pembelajaran kewirausahaan, guru harus memberikan tugas dengan tingkat kesulitan yang berbeda. Hal ini bertujuan untuk meningkatkan kepercayaan pada kemampuan mereka dan mendapatkan pelatihan untuk melacak perkembangan bisnis di sekitar mereka.

\section{DAFTAR RUJUKAN}

Agusmiati, D., \& Wahyudin, A. (2019). Pengaruh Lingkungan Keluarga, Pengetahuan Kewirausahaan, Kepribadian, Dan Motivasi, Terhadap Minat Berwirausaha Dengan Self Efficacy Sebagai Variabel Moderating. Economic Education Analysis $\quad$ Journal, 7(3), 878-893. Https://Doi.Org/10.15294/Eeaj.V7i3.28317

Anggraeni, Bety, H. (2015). Pengaruh Pengetahuan Kewirausahaan Dan Lingkungan Keluarga Terhadap Minat Berwirausaha Siswa Kelas Xi Smk Islam Nusantara Comal Kabupaten Pemalang. Pengaruh Pengetahuan Kewirausahaan Dan Lingkungan Keluarga Terhadap Minat Berwirausaha Siswa Kelas Xi Smk Islam Nusantara Comal Kabupaten Pemalang, 10(1), 4252. Https://Doi.Org/10.15294/Dp.V10i1.5093

Ariesta, R. P. (2017). Jurusan Pendidikan Ekonomi Fakultas Ekonomi Universitas Negeri Semarang 2015. Pengaruh Kompetensi Akuntansi Dan Komputer Terhadap Hasil Belajar Komputer Akuntansi Myob Dengan Computer Attitude Sebagai Variabel Intervening Pada Siswa Kelas Xi Akuntansi Smk $\begin{array}{lllll}\text { Batik Sakti } & 1 & \text { Kebumen, } & 1(1),\end{array}$ Https://Lib.Unnes.Ac.Id/29614/1/7101413025.Pdf

Astri Srigustini. (2014). Pengaruh Efikasi Diri, Pengetahuan Kewirausahaan Dan 
67 | Jurnal Pendidikan dan Kewirausahaan Vol. 9 No. 12021

Kecakapan Vokasional Terhadap Sikap Wirausahaserta Implikasinya

Terhadap Minat Berwirausaha Siswa Smk Berdasarkan Bidang

Studikeahlian(Survey Pada Siswa Smk Kelas Xi Se-Kota Tasikmalaya)

[Universitas Pendidikan Indonesia]. Http://Repository.Upi.Edu/12319/

Boyke P. Siregar. (2021). Akibat Pandemi Covid-19, Jumlah Pengangguran

$\begin{array}{llll}\text { Bertambah } & 1,82 & \text { Juta. }\end{array}$

Https://Www.Wartaekonomi.Co.Id/Read340395/Akibat-Pandemi-Covid-19-

Jumlah-Pengangguran-Bertambah-182-Juta

Insonia Mardatilah, H. (2020). Faktor Penyebab Rendahnya Minat Mahasiswa

Kepelatihan Terhadap Kewirausahaan. Jurnal Patriot, 2(1), 327-335.

Irda. (2019). Pengaruh Pengetahuan Kewirausahaan Dan Lingkungan Keluarga

Terhadap Minat Wirausaha Siswa Smk Negeri 1 Makassar [Universitas

Negeri Makassar]. Http://Eprints.Unm.Ac.Id/12630/1/Skripsi Irda Fe Unm.Pdf

Nasution, M. F., \& Panggabean, S. M. (2019). Pengaruh Pengetahuan

Kewirausahaan Dan Pendapatan Orangtua Terhadap Minat Berwirausaha Siswa Kelas Xii Pemasaran Smk Negeri 7 Medan T.A 2018/2019. Niagawan, 8(1), 16. Https://Doi.Org/10.24114/Niaga.V8i1.12802

Novi Trisnawati. (2014). Pengaruh Pengetahuan Kewirausahaan Dan Dukungan

Sosial Keluarga Pada Minat Berwirausaha Siswa Smk Negeri 1 Pamekasan

Novi. Jurnal Ekonomi Pendidikan Dan Kewirausahaan, 2(1), 57-71.

Suryana. (2013). Kewirausahaan: Kiat Dan Proses Menuju Sukses. Salemba Empat.

Untag Teddy Wijaya. (2014). The Effects Of Entrepreneurship Knowledge And Self-Concept On. E-Jurnal Pendidikan Teknik Mesin, 2(2), 1-7. 